\title{
A Case for Non Interest Banking in Nigeria amidst the Collapsing Paradigms in the Global Economy
}

\author{
Lionel Effiom (Corresponding author) \\ Department of Economics, University of Calabar, Calabar, Nigeria \\ Tel: 234-80-3088-7565; 234-80-5318-4609_E-mail: leoeff2002@yahoo.com \\ Peter Samuel Ubi \\ Department of Economics, University of Calabar, Calabar, Nigeria \\ Tel: 234-80-3507-2890Ｅ-mail: Ubipetersamuel@yahoo.com \\ Emmanuel O. Okon \\ Salem University, Lokoja, Nigeria \\ E-mail: Tonydom57@yahoo.com
}

Received: December 23, 2011

Accepted: May 19, 2012 Published: July 15, 2012

doi:10.5430/ijba.v3n4p20

URL: http://dx.doi.org/10.5430/ijba.v3n4p20

\begin{abstract}
This paper argues for reconsideration and reevaluation of the underlying assumptions and paradigms of the world capitalist system in particular and that of economics in general. This is against the backdrop of an increasing discontent of majority of the world's people against the growing inequality between the rich and the poor. It contends that the genesis of the problem is rooted in the concept of the selfish, individuated economic man, which has fueled our appetite for greed, selfishness and unbridled primitive capitalist accumulation. Thus these clannish and narrow assumptions must be relaxed to bring in the more altruistic, non-material components of man. This new philosophy and concept of our economic man incidentally aligns with the principles of Islamic banking, a variant of non-interest banking. But it cautions that the imperatives of citizen education and a de-emphasis on religious sentiments are central to guaranteeing the success of the programme.
\end{abstract}

Keywords: Non-interest banking, Crumbling orthodoxy, Economic man, Paradigm shift

\section{Introduction}

The current recession, also termed melt down, started in 2007 due to the subprime mortgage crises in the US, and the latter and other Western nations have been struggling to come out of it. The recent downgrading of US credit rating and the political row over its debts ceiling have not helped but worsened conditions in the world economy. Austerity measures, financial bailouts, socio-political unrest in Greece, Ireland and Spain; Italy's mounting fiscal deficit and austerity packages, its floundering fiscal policy proposals; Germany's reluctance to mop, buy and hold the debts and deficits of its European partners - these all are indices of a sickening global economic condition which calls for drastic measures. And there are fears that the world economy may be at the precipice of another recession, possibly a depression. Political casualties have emerged as the euro zone crises continue to defy all known traditional policy prescriptions: the prime ministers of Greece as well as Italy have resigned on allegations of poor handling of the crises in their national economies. And there are palpable fears that the financial crises, particularly in the Eurozone, could spread to other continents, thus further compromising the ability of sovereign states to tackle the crises.

Several nations, particularly Nigeria, have responded by proposing policies towards the enthronement of a radical banking regime, in many ways opposed to the conventional banking practices, but meant to run concurrently with the latter. This is known as non-interest banking, of which Islamic Banking is one of its variants. Expectedly, this has generated heated debate and further polarized the country along macro ethnic and religious lines. But is there any merit in the so called non-interest banking? What is the basis for the renaissance in Islamic banking? One thing should be made clear - the 
renewed interest in Islamic banking cannot be unconnected to the inability of traditional theories and policies governing conventional banking practices to bring an end to the financial crises. Could it be that the age-long economic policies of the West have become trite, worn-out and incapable of substantially and permanently redressing the global economic downturn? Has the time come for a serious consideration of the underlying ideologies and paradigms of Economics as a discipline which manifest themselves in the unpleasant conditions we are presently grappling with? This paper addresses these issues. Following this introduction is section 2 which reviews the theoretical and empirical literature, followed by section 3 which attempts an overview of the Nigerian banking industry from the Structural Adjustment Reform Programme through the Banking Sector Consolidation and Recapitalization Programme to the post-consolidation reform process. Section 4 examines the collapsing paradigms within the broader ambience of Economics as a social science, while section 5 evaluates the imperatives of a paradigm shift, making a case for non-interest banking. Section 6 concludes the paper.

\section{Theoretical Considerations}

The theory of financial intermediation basically concerns itself with why banks exist at all, what roles they play and their relevance in economic development. In answering these questions, traditional theory maintains that intermediaries exist because of transaction costs, asymmetric information between borrowers and lenders, as well as different requirements for lenders and borrowers. For instance, firms borrowing funds to finance investment will tend to want to repay the borrowing over the expected life of the investment. In addition the claims issued by firms will be have a relatively high default risk reflecting the nature of business investment. In contrast, lenders will generally be looking to hold assets which are relatively liquid and low-risk. To reconcile the conflicting requirements of lenders and borrowers a financial intermediary will hold the long-term, high-risk claims of borrowers and finance this by issuing liabilities, called deposits, which are highly liquid and have low default risk. On the other hand, transaction costs are of four types, namely, search, verification, monitoring, and enforcement costs. In the first, both lender and borrower will incur costs of searching for and finding information about a suitable counterparty; in the second, lenders must verify the accuracy of the information provided by borrowers; in the third, once a loan is created, the lender must monitor the activities of the borrower, in particular to identify if a payment date is missed; and lastly, the lender will need to ensure enforcement of the terms of the contract, or recovery of the debt in the event of default. Diamond (1984) offered the first coherent explanation for the existence of financial intermediaries. Here, the intermediary "monitors" borrowers on behalf of investors who lend to the intermediary. But, then it would appear that the lenders to the intermediary have to "monitor" the intermediary itself. This problem, which has come to be known as the "monitoring the monitor" problem was recognized and solved in Diamond (1984).

To be more precise, the problem of "monitoring the monitor" is this: lenders to the intermediary can reduce monitoring costs if the costs of monitoring the intermediary are lower than the costs of lenders lending directly to borrowers and directly incurring the monitoring costs. Diamond's fundamental result is to show that as an intermediary grows large, it can commit to a payment to depositors that can only be honored if, in fact, the intermediary has monitored as it promised. If not, then the intermediary incurs nonpecuniary penalties, interpreted by Diamond as bankruptcy costs or loss of reputation.

To formalise the argument, we follow Williamson's (1986) presentation of the Diamond result; unlike Diamond, it does not rely on precise contractual specification of nonpecuniary penalties, which is rarely seen in practice. A brief outline of the essential part of the Williamson model is as follows. Borrowers need resources to invest in their projects. They invest $\mathrm{K}$ units of endowment at date 0 and receive $\mathrm{w} \sim \mathrm{K}$ at date 1 , where $\mathrm{w} \sim$ is a random variable distributed according to the density $\mathrm{f}(\mathrm{w})$. As shown by Gale and Hellwig (1985), the optimal contract between the borrower and a lender is a debt contract. At date 1 borrower $\mathrm{j}$ has a realized return of wj per unit invested. Borrower $\mathrm{j}$ pays the lending intermediary a gross rate of return $\mathrm{R}$ in a state, wj, where there is no monitoring and $\mathrm{R}(\mathrm{wj})$ when there is monitoring. Define the $\mathrm{set} B=\{w j: \mathrm{R}(w j)$ $<\mathrm{R}\}$ and $\mathrm{Bc}=\{\mathrm{wj}: \mathrm{R}(\mathrm{wj}) \leq \mathrm{R}\}$. Finally, let $\mathrm{r}$ denote the certain market return, required by risk neutral investors. When the intermediary has $\mathrm{m}$ borrowers, each investing $\mathrm{K}$, then the total return to the intermediary (before compensating depositors) is:

$$
\begin{aligned}
& \pi_{\mathrm{m}}=\mathrm{K} \Sigma \min \{\mathrm{R}(\mathrm{wj}), \mathrm{R}\} . \\
& \mathrm{j}=1
\end{aligned}
$$

By the strong law of large numbers:

$\underline{1}$

$$
\operatorname{Plim} \mathrm{m} K \pi \mathrm{m}=\int \mathrm{R}(w \mathrm{w}) \mathrm{dwj}+\int \mathrm{f}(w \mathrm{w}) \mathrm{dwj}
$$

$\mathrm{m} \rightarrow \infty \quad$ B $\quad$ Bc 
Consequently, since the intermediary's return must be at least the market return, $r$, if the following inequality holds:

$$
\int R\left(w_{j}\right) f\left(w_{j}\right) d w j+R \int f\left(w_{j}\right) d w j-(C / K) \int f\left(w_{j}\right) d w_{j} \geq r
$$

$\mathrm{B} \quad \mathrm{Bc} \quad \mathrm{B}$

Then, as the intermediary grows large, it can guarantee a certain return of $\mathrm{r}$ to its depositors.

If the intermediary is finite sized, that is, it lends to a finite number of borrowers, then depositors must monitor the intermediary to ensure that the intermediary, in turn, is monitoring the borrowers. Since monitoring is costly, and given the certain market return that must be obtained, the depositors must be compensated for these monitoring costs by the intermediary. Compensating the depositors for monitoring costs incurred, lowers the profitability (utility) of the intermediary. However, the central result of Diamond (1984) applies here, namely, that the depositors need not monitor an infinitely large intermediary because such a firm can achieve $r$ with probability one. In the limit, depositors do not need to monitor the intermediary. The "monitoring the monitor" problem is solved by diversification.

\subsection{The Problem of Asymmetric Information and Transaction Cost}

Asymmetric information refers to the situation where one party to a transaction has more information than the other party. This is a problem with most types of transactions, not just financial. In the case of a financial transaction, the borrower will have more information about the potential returns and risks of the investment project for which funds are being borrowed compared to the lender. The existence of asymmetric information creates problems for the lender, both before the loan is made, at the verification stage and after, at the monitoring/enforcement stages. The first problem created by asymmetric information occurs when the lender is selecting a potential borrower. Adverse selection can occur because the potential borrowers, who are the ones most likely to produce an adverse outcome, are the ones most likely to be selected. The second problem that arises out of asymmetric information is moral hazard. This is a problem that occurs after the loan is made and refers to the risk that the borrower might engage in activities that are undesirable (immoral) from the lenders point of view, because they make it less likely that the loan is repaid. A person is more likely to behave differently when using borrowed funds compared to when using their own funds. In particular they may take more risks with the funds.

Thus, the existence of transaction costs and information asymmetries are important impediments to well functioning financial markets. Although the existence of organized markets where tradeable debt and equity instruments can be issued and acquired (i.e. the bond and equity markets) overcome some of these obstacles, there are still substantial transaction costs and high-risk for the lender, and the problems associated with asymmetric information cannot be fully overcome in this way. The solution to these problems has been the emergence of financial intermediaries such as banks.

The above analysis of traditional theories of intermediation which are based on transaction costs and asymmetric information are designed to account for institutions which take deposits and channel funds to firms. In recent decades however, there have been significant changes which tend to reduce the relative importance hitherto placed on asymmetry and transaction cost. Revolution in information communication and technology has hugely narrowed the gap of information between lender and borrower, yet intermediation instead of decreasing has continued to increase with new banks emerging every year. New markets for financial futures and options are mainly markets for intermediaries themselves, rather than for individuals or firms. This then calls into question the adequacy of traditional theories in explaining the existence of intermediaries.

Allen and Santemero (2006) provide an alternative view to traditional theories of financial intermediation. They argue that intermediaries have, in keeping pace with a rapidly changing world, assumed roles of facilitators of risk transfer as well as those which deal with the increasingly complex maze of financial instruments and markets. Thus risk management has become a key area of intermediary activity. They submit that the traditional distinction between financial markets, where securities are issued by firms and directly owned by individuals, and intermediaries, where depositors and policyholders provided funds to banks and insurance companies who lent out these funds, has broken down. Financial markets for equity and debt are becoming increasingly dominated by intermediaries such as mutual and pension funds. The volume of transactions in these markets and those trading more complicated financial claims has become dominated by these same intermediaries, as well as the participants representing the standard institutions, i.e., commercial and investment banks and insurance companies. Indeed, the operations of many large banks and insurance companies have changed dramatically over this period, with trading activity occupying the bulk of their efforts. The increased use of securitization of loans has exacerbated this trend in that it has altered the lending functions performed by banks. Now much of the asset origination activity is merely the first step to asset sales or complex stripping and repackaging. At the very least, such assets are viewed as available for sale.

However, perhaps the most significant trend that is evident is the increased concentration by banks and insurance companies as well as other financial institutions in the business of asset trading and risk shifting. The huge amounts of 
derivatives outstanding and the turnover suggest that this has become a major, and perhaps the most important, activity for the sector. These trends have not been captured by orthodox intermediation theory, and therefore less satisfactory.

\section{Overview of the Nigerian Banking Industry}

The Nigerian banking industry has remained one of the most vibrant and robust in the ECOWAS sub-region and indeed in Africa. This is partly because of the yawning gap existing between the surplus and the deficit spending units. Besides, Nigeria's population makes it the largest market in Africa, a condition which supports and encourages private sector driven initiatives. With robustness of the industry also come many challenges which have compromised the stability and efficiency of the industry. In effect, the industry has a history intertwined with that of the Nigerian economy as a whole. It has been at the receiving end of the various reform regimes that have been undertaken by the government over the years. Of significance is the Structural Adjustment Programme initiated and implemented by the Babangida's Administration in 1986, the 2005 banking sector reforms and its ancillary aftermaths in 2008.

\subsection{Structural Adjustment Reform Programme}

Onwioduokit and Adamu (2006) note that by 1987 when the financial sector underwent a comprehensive reform, the sector was highly repressed. Interest rate controls, selective credit guidelines, ceilings on credit expansion and use of reserve requirements and other direct monetary control instruments were conventional characteristics of the financial system. Access into banking business was limited and government-owned banks dominated the industry. The reform of the foreign exchange market, which until then was also controlled, began in 1986.

The main financial sector reform policies applied were deregulation of interest rates, exchange rates and access into banking business. Other reform measures included establishment of Nigerian Deposit Insurance Corporation, strengthening the regulatory and supervisory institutions, upward review of capital adequacy standards, capital market deregulation and introduction of indirect monetary policy instruments. Some distressed banks were liquidated while the CBN took over the management of others. Government share holdings in some banks were also sold to private sector.

The Central Bank of Nigeria made attempts at restructuring the financial system prior to the introduction of open market operations in 1993. Bank deposit and lending rates were deregulated at the beginning of the SAP in 1987. In 1991 the CBN, in a reaction to rising nominal lending rates in the market for loans, prescribed a maximum margin between the bank's average cost of funds and their maximum lending rates as well as a minimum level for their savings deposit rates. Interest rate determination was still supposed to be market-related through its link to the cost of funds.

In order to promote competition in the money market, the procedure for licensing new banks was streamlined and liberalized. Consequently, the number of banking institutions increased from 50 in 1987 to 120 in 1993 and dropped to 115 in 1996. By 1998 the number of banks surged to155. In 2004 however, the number plummeted to 89. Evidence from Table 1 below shows that the growth in the number of banks during the pre-SAP era was not significant. For instance, the number of commercial banks increased from 14 to29 between 1970 and 1986, representing an average annual growth rate of 5.0 per cent. Consequent upon the liberalization of the sector, the number of operating banks almost doubled within three years into the reform and tripled in the fifth year. The number of commercial banks increased from 34 in 1987 to as high as 90 in 2003. Although commercial banks experienced an astronomical increase in number during the reform era, the rate of growth in the number of bank branches appears to be low when compared to pre-reform era. For instance the average annual growth rate of the number of commercial bank branches was 10.0 per cent between 1970 and 1986, which is much higher than the 3.0 per cent recorded during the period 1987 to 2003 . With respect to merchant banks, the number of banks grew by 19.0 per cent between 1986 which is also higher than the 8.7 per cent recorded during the 1987 to 2003 period. The number of branches also grew by 47.6 per cent between 1970 and 1986 which is much higher than 9.9 per cent recorded between 1987 and 2003.

Adeoye and Adewuyi (2006) observe that the phenomenal increase in the growth of the number of banks during the reform era did not appear to have had major impact on the concentration and the oligopolistic nature of the industry and savings mobilization capacity. For instance, the share of the three largest banks in total assets of the industry decreased from 37.3 per cent before the reform to an average of 34.6 per cent over the reform period, a reduction of only 2.7 per cent points despite the over 200 per cent growth of operating institutions. Furthermore the new banks were generally small and undercapitalized, a situation that later justified an upward review of banks minimum operating capital (Emenuga, 2005). The Nigeria Deposit Insurance Corporation (NDIC) in its 1996 annual report put the number of distressed banks at 50 with N65.13 billion assets trapped. These banks had offered N50.55 billion loans, N40 billion or 79 per cent of which were classified as nonperforming credits. The liquidation of 26 banks put N16 billion or 32 per cent at risk since only N5 billion is insured by NDIC. More so that the N20 billion or 40 per cent worth of loans disbursed by these banks were hardly recoverable. Between 1994 and 2002, a total of 33 banks were closed. 
Within the African continent, Brownbridge (1998) submits that the growth of local banks was mainly due to a combination of low entry requirements and the perception that banking provides opportunities for profit not available in many other sectors of the economy. In all of the countries where local banks were set up in significant numbers, the regulatory barriers to entry were low. Before they were revised (which in most Anglophone African countries was not until the late 1980s or early 1990s) the banking laws did not impose stringent requirements on applicants for bank licenses in terms of relevant expertise, and did not specify grounds for rejection of applications. He further avers that, in Nigeria for instance, crass political interference subverted prudential criteria in the granting of licences; retired military officers were directors of many banks (Lewis and Stern, 1997, p. 7), and in Kenya many banks had prominent politicians on their boards. The minimum capital requirements to set up a bank were low, mainly because the real value of the nominal requirements specified in the banking legislation had been eroded by prolonged inflation.

Low entry barriers, however, would not by themselves have stimulated local investors to enter financial markets; profitable opportunities were perceived to exist in these markets. Because of the high gearing involved in banking, however, it did offer investors opportunities to make high returns to their capital provided that deposits could be mobilized and sufficiently remunerative investment outlets found (Brownbridge, 1998). He enumerated several reasons why banking attracted local investors. First, investors perceived opportunities to exploit gaps in financial markets; Second, the liberalization (or partial liberalization) of financial and foreign-exchange markets provided banks with opportunities to generate profits from treasury operations and foreign-exchange dealing.

Third, some of the local banks in Africa had been set up with less ethical motives in mind. The extent of insider lending was considerable, suggesting that some of the local banks were set up to enable their owners to mobilize funds for their other business ventures. Table 3 below specifically exposes this unpleasant scenario in the Nigerian banking industry. It reveals for instance that the ratio of insider loans to total loans ranged from 55 per cent to over 90 percent while the ratio of non-performing loans to total loans was over 90 per cent. In fact, for Commercial Trust Bank, liquidated in 1998, absolutely all the loans it lent out was non-performing. These ugly trends were due to prevalence of overextension, mismatch of assets and liabilities, lack of standard practices and ineffective internal control systems (Alashi, 2002; Adam, 2004).

Another major policy that affected the Nigerian banking industry was the 2005 Consolidation Programme. Like the previous reform regimes, the Nigerian banking industry before the 2005 consolidation programme was fragile and marginal, with debilitating ability to finance major investments in the real sector of the economy. Conditions such as persistent illiquidity, weak corporate governance, poor assets quality, insider abuses, weak capital base, unprofitable operations, and over-dependency on public sector funds, among others, necessitated the banking sector reform. Thus at the end of recapitalization 25 banks emerged as having met the N25bn recapitalization requirement. The structure of the "Consolidated Banks" comprises of those that "stand alone", to two to nine "merged banks". The programme resulted in the shrinkage of the number of banks from 89 to 25 through merger/acquisition involving 76 banks which altogether account for $93.5 \%$ of the deposit share of the market (Soludo, 2005).

\subsection{Post-Consolidation Reform Process}

The post consolidation scenario can best be captured in the words of Sanusi (2010) where he observed that "the Nigerian banking sector witnessed dramatic growth post-consolidation. However, neither the industry nor the regulators were sufficiently prepared to sustain and monitor the sector's explosive growth. Prevailing sentiment and economic orthodoxy all encouraged this rapid growth, creating a blind spot to the risks building up in the system." In other words, the consolidation programme had at least achieved some of its objectives, namely, strengthening and positioning the industry for greater capacity to deal with mega international investments and global competitiveness. At the threshold of the 2007 recession, this achievement perhaps influenced the CBN to assure Nigerians that the Nigerian economy and particularly the banking industry were insulated from the emerging economic tsunami. But these assertions were proved later to be an expression of either an over confidence, or a lack of analytical competence of the economy, or a sincere attempt to calm the nerves of a disquiet nation. Problems in the banking industry included macro-economic instability caused by large and sudden capital inflows; major failures in corporate governance at banks; lack of investor and consumer sophistication; inadequate disclosure and transparency about financial position of banks; critical gaps in regulatory framework and regulations; uneven supervision and enforcement; unstructured governance \& management processes at the $\mathrm{CBN} /$ weaknesses within the $\mathrm{CBN}$; and weaknesses in the business environment.

Macro economic instability was induced by persistent rise in the price of oil between 2004 and 2008, resulting in a corresponding rise in government expenditure and appropriation of the excess crude oil revenues to the different tiers of government. Variations in monthly disbursement of oil revenues made it difficult for governments to manage economic development and caused tremendous instability as these varying amounts entered the banking sector. Fiscal policy then 
became highly pro-cyclical. The speed of credit creation accelerated with the combined effects of the consolidation and abundant capital due from oil. Thus bank deposits and credit, which kept pace with the rising oil price, grew four-fold from 2004 to 2009 and banking assets grew on average at 76\% per annum since consolidation (Sansui, 2010). All these happened at a time of feeble corporate governance standards at banks.

This was exacerbated with the Consolidation which created bigger banks but failed to overcome the fundamental weaknesses in corporate governance. Besides CBN examinations revealed that most banks were engaged in unethical and potentially fraudulent business practices with profound depth and scope. Banks took advantage of consumer and investors ignorance of the workings and dynamics of the financial system and stock market. With zero consumer activism or investor protection, many Nigerians made investments without a proper understanding of the risks. In summary "the prevailing view that the sector was healthy, a culture of tolerance, and acceptance of the status quo and the shortage of specialist skills compromised supervision's effectiveness". By and large, the CBN and its leadership were responsible for the post-consolidation banking crises: "the governance and management processes at the CBN also had a significant impact on its ability to deliver its mandate adequately. Governance and internal processes were unstructured and this compromised the CBN's ability to supervise the industry. Corporate governance at the CBN was laissez-faire... and there were inadequate committee structures and processes to ensure the CBN Board's independence in assessing whether the $\mathrm{CBN}$ was fulfilling its mission. Issues concerning the stability of the financial sector and economic development were not discussed comprehensively at the CBN Board meetings- these risks include for example, global economic risks, federal / state economic development strategies and fiscal policies, formation of asset bubbles, exchange rate risk, capital market depth, informal sector economy etc. (Sanusi, 2010)

Consequently, the response was swift and earthshaking; its reverberations ran through the entire industry. Chief executives officers of some banks were sacked, legal processes were initiated against them, and above all capital was injected into the distressed banks to restore investor confidence. The CBN also introduced tenure limits for bank CEOs and intend to implement the term limits set out in the 2006 Code of Conduct for the banking Industry with respect to non executive directors and auditors in the immediate future. In summary, the CBN has initiated a holistic response to the malaise plaguing the banking industry. These response rest on four pillars, namely, enhancing the quality of banks; establishing financial stability; enabling healthy financial sector evolution; and ensuring the financial sector contributes to the real economy

\section{The Collapsing Paradigms}

The paradox in this unfolding economic saga is that the Eastern block of developed nations led by China, the world's second largest economy, seem to be insulated as it were from the menacing misfortunes ravaging the Western economies. The only worry China seems to have is that, as a major player in the world economy, whatever affects America, her major trading partner, would directly affect her. Secondly, China is the largest holder of US debts in the form of bonds and so should be concerned about economic developments in the US and indeed the Euro zone. It has been exciting and interesting listening to the Finance Minister of China offering prescriptions on how the West should run their economies, something unthinkable in past decades. Could it be that the Western Model of capitalism cannot be trusted in the $21^{\text {st }}$ century, or needs some modification? Is the process of economic education and re-engineering assuming opposite trends, that is, moving from East to West and not vice versa consistent with entrenched orthodoxy? It is within this context that we examine some of the fundamentals of the Western banking system which has existed for centuries now. The aim is to discover whether there exists some underlying weakness which gives vent to the persistence of bubbles and burst, cycles and instability in the economy. This undertaking means a direct analysis of the superstructure of capitalism, for the banking industry is merely a lengthened shadow of the many arms and variants of capitalism. Nor would the evaluations stop there; it must of necessity dialectically articulate the micro foundations of economics itself as a social science, for "the warp and weft" of capitalism is in essence a voyage in economics.

We begin our analysis with the concept of the economic man which is the foundation of economics. Garba (2003) argues that our knowledge of the term economic man can be enhanced if we approached the term in two dimensions, namely, the conceptual and the analytic. The latter would yield a defective comprehension of the term while the former would provide a holistic picture. Analytically, the economic man is known to be rational; but the conceptual clarifications reveal definite, underlying metaphysical questions about his existence. Conceptually, one is an economic man if he has a free will, has perfect knowledge, prefers pleasure to pain, chooses independently, would choose the most preferred option if that option is available, and is selfish. Our concern here is with the last conceptual attribute of our "man" - that he is selfish. This raises ethical questions about the propriety of selfishness and the morality of a being who is rabidly obsessed with the desire to seek maximum advantage to him self alone, to the exclusion of others who share a common humanity with him. 
Wherein lies the sense of love and brotherhood? We shall show later that the recurring and persistent crisis facing the world economy can largely be explained within the ambit of this false foundation.

It is indeed unfortunate that economics, unlike many others, was crafted and built on this wrong philosophical notion of selfishness and greed. Essia (2005) submits that the real man is by no means the economic man of neoclassical economics; he is not just an atomistic agent but can be better described as an interacting agent. It is perverse to think that man is naturally motivated by self-seeking drives alone, when there are indeed other social and cosmopolitan drives. Thus economists cannot successfully comprehend human behaviour simply by concentrating on the self-seeking drives alone. This preoccupation with self-interest brings economics and its various outworkings at the market place, banking hall, production points, etc within the orbit of materialism and the measurable aspects of material existence, and in the process we ignore or assume away the non-material realities, largely because of measurement difficulties.

The pervasive massive outcry against corruption in our private and public life is indicative of the fact that the self-interest ideology should be discarded or, better still and more leniently, augmented with non-material aspects of man. This should include love, empathy, kindness, fairness, etc. The non-measurability of these ideas should not obviate the need of emphasizing them and perhaps incorporating them into a new grand theory proposed by Ekpo (2009). Over-invoicing, inflation of contract sums, production and proliferation of sub-standard goods, abandonment of projects midstream even when contracts sums have been paid, high interest rates charged on loans but a laughable, sticky and marginal rate on deposits - all these demonstrate the base tendencies of man, which economics and Western ideologies tacitly promote. What other causes could one possible advance to justify the fact that "CEOs set up Special Purpose Vehicles to lend money to themselves for stock price manipulation or the purchase of estates all over the world. One bank borrowed money and purchased private jets which we later discovered were registered in the name of the CEO's son. In another bank the management set up 100 fake companies for the purpose of perpetrating fraud. A lot of the capital supposedly raised by these so called "mega banks" was fake capital financed from depositors' funds. $30 \%$ of the share capital of Intercontinental bank was purchased with customer deposits. Afribank used depositors' funds to purchase $80 \%$ of its IPO. It paid N25 per share when the shares were trading at N11 on the NSE and these shares later collapsed to under N3. The CEO of Oceanic bank controlled over $35 \%$ of the bank through SPVs borrowing customer deposits. The collapse of the capital market wiped out these customer deposits amounting to hundreds of billions of naira." (Sanusi, 2010)

All over the world, politicians, statesmen, technocrats and policy makers are seeking for new ways to solve protracted problems that defy solutions. Many challenges facing the human race (be it at the economic, political or social sphere) have remained intractable because of the increasing complexity of our world and the persistence in situating solutions and panacea strictly within orthodox or conventional moulds. Take for instance the issue of terrorism, the developed West have lately discovered that the war on terror cannot be won simply through military might alone. The increasing sophistication of terrorists, their ruthless and savage determination, and most importantly, their facelessness and ambiguity, have combined to make the West rethink of finding solutions just within traditional orbits alone. Thus they have begun talking and dialoguing with the Taliban. It is our proposition that such approach should form our considerations in our search for new and meaningful realities for the Nigerian economy. We cannot continue to dither and flounder with worn out models and orthodoxies that we know for certain cannot last. As Essia (2005) points out, the relevance of economics lies in its capacity to address the material requirements of a changing world. But while the fact of change remains, human beings often find it difficult to change. The speed of change in economic thought lags behind the economic conditions that would suit the natural evolution processes. Economic thinking tends to be more reactive or responsive and less proactive. This intellectual gap in economic thought is linked here to the colonization of human thinking generally and economic thought in particular by Western ideologies. Modernization, development and civilization are broadly conceived in terms of Westernization. This has hindered the capacity of people to independently identify how, why and when to change.

Thus the economic condition that confronts us in this $21^{\text {st }}$ century calls for a new deal, a new approach by economists to radically alter our thought patterns. This was the situation that Keynes found himself in the 1930s, and while writing the General Theory, he confided in a friend thus: I am writing a book that will fundamentally change economic thinking. Our present circumstances are not less different. We should not be held hostage by outmoded ideologies, which are actually the mental creations of those who are able to extend their mental structures to others. In many cases, ideologies are drawn from the thoughts and rationalizations of dominant groups that are able to colonize the mental models of others. And we must be ready to embrace the change no matter which side of the religious or political divide it emerges. The entire world cannot all be pro-western. We shall now turn our attention to the concept of Islamic banking and the need to give it a fair trial. This would be the new paradigm in the banking industry. 


\section{Imperatives of a Paradigm Shift}

From the preceding section, we have shown that all is not well with the world economy and that its present crises have historical antecedents that are bound to reoccur because of the fundamental problems in our ideology. Capitalism is intrinsically unstable. Here, like Keynes, we are not advocating an overthrow of capitalism, but adducing suggestions to make it work better for the benefit of not just a few as is presently the case, but for all.

\subsection{A Case for Non-Interest Banking}

Nigeria, and indeed much of the ECOWAS sub-region, is a polarized country. Ethnic, religious, cultural and sociological divisions hold sway. In such situations, the use of terms must be applied with wisdom. While the basic concept of this banking model rest on Islamic law, it is preferable to strip the phenomenon of any religious or sectarian epithets and rather adorn it with a more secular and congenial label - non interest banking. Furthermore, Islamic banking is one of the several components of non-interest banking. But here, our advocacy is for the Islamic brand and herein specifically referred to as non-interest banking.

Non-interest banking is a banking model which is based on Profit and Loss Sharing (PLS) system. It rests on Islamic doctrine of 'universal permissibility' in business dealings, which states that: "everything is permissible unless it is clearly prohibited". Islamic banking is expected to give depositors another choice of where to invest their wealth. In this dispensation, the customer and the bank share the risk of any investment on agreed terms, and divide any profits that accrue therefrom. Non Muslims are also not excluded. While non-Islamic countries like United Kingdom, Germany and South Africa have championed the practice of Islamic banking amongst the 75 countries practicing it, South Africa's Stanbic IBTC bank had since signified its interest to the CBN for a licence to practice Islamic banking.

Its principles are not considerably different from that of conventional banking. Banks, like every private firm exist to make profit; banking institutions under this regime also exist to make profit by lending capital. Besides the PLS technique, other principles used include safekeeping, joint venture, cost plus and leasing.

An interesting analysis of the principles of non-interest banking of the Islamic type is provided by Wikipedia: "In an Islamic mortgage transaction, instead of loaning the buyer money to purchase the item, a bank might buy the item itself from the seller, and re-sell it to the buyer at a profit, while allowing the buyer to pay the bank in installments. However, the bank's profit cannot be made explicit and therefore there are no additional penalties for late payment. In order to protect itself against default, the bank asks for strict collateral. The goods or land is registered to the name of the buyer from the start of the transaction. This arrangement is called Murabahah. Another approach is EIjara wa EIqtina, which is similar to real estate leasing. Islamic banks handle loans for vehicles in a similar way (selling the vehicle at a higher-than-market price to the debtor and then retaining ownership of the vehicle until the loan is paid)".

Transactions on home loans are guided by the Musharaka al-Mutanaqisa principle, which allows for a floating rate in the form of rental. The bank and borrower form a partnership entity, both providing capital at an agreed percentage to purchase the property. The partnership entity then rents out the property to the borrower and charges rent. The bank and the borrower will then share the proceeds from this rent based on the current equity share of the partnership. At the same time, the borrower in the partnership entity also buys the bank's share of the property at agreed installments until the full equity is transferred to the borrower and the partnership is ended. If default occurs, both the bank and the borrower receive a proportion of the proceeds from the sale of the property based on each party's current equity. This method allows for floating rates according to the current market rate such as the base lending rate, BLR.

Khan (2006) furnishes evidence on four issues relating to Islamic banking. First, he demonstrates that Islamic banking system can be formulated in a neoclassical framework; second, when cast in this formal way, the model underlying Islamic banking is not totally alien to conventional economic thinking (indeed, it is pointed out that variants of such a system have appeared in the writings of a number of eminent economists, such as Fisher, Simons, and Friedman; third, that there may be circumstances in which an Islamic banking system would be relatively more stable than the traditional interest-based banking system in the face of certain types of shocks; finally, he proposes how the Islamic banking system should be implemented so as to maximize its inherent benefits. With a growth rate of 10 to 15 per cent per year, Islamic banks have more than 300 institutions spread over 51 countries, including the United States. This is in addition to 250 mutual funds that comply with Islamic principles. The Economist (2009) estimates that over US\$822 billion sharia-compliant assets are managed worldwide, representing approximately $0.5 \%$ of total world estimated assets as of 2005 (Slater, 2007). It has been even suggested by the Vatican that "the principles of Islamic finance may represent a possible cure for ailing markets.

As shown earlier, the conventional banking system has no doubt contributed to the economic development of nations through its intermediation role between the deficit and the surplus spending units. However, it is also true that many have been rendered miserable and frustrated by the overbearing interest rates on loans charged by banks. The irony is that while 
lending rates are always in an upward trajectory, deposit rates are pitiably low. A case for non-interest banking would therefore bridge this gap between deposit rate and lending rate; more so as the banker sees the business of his client as his own, and does anything legally to ensure his client succeeds. The banker does this knowing that the success of his client is his success. Such conditions are unthinkable in the extant conventional banking. Here, the banker is a complete alien, most times having a disposition that he his doing his client a world of good by lending to him. If the non-interest banking regime is gradually built into the Nigerian financial space, the issues of greed, highhandedness, selfishness and corruption would slowly be checked. The process of change may be slow and tough, but it would certainly be worth the trouble.

This shift in paradigm must not be hasty and clumsy in its processes and implementation. First, it calls for adequate education of the Nigerian populace. Discourses on these issues should be encouraged; the academia and other stakeholders should take the lead in promoting healthy debate on all aspects of the non-interest banking. Second, the idea should be stripped of its religious toga, as this would further accentuate the polarization of the already battered system. Finally, a level playing field should be created for everyone willing to participate in this new banking regime.

\section{Concluding Remarks}

Our purpose was to show that the Nigerian banking industry needed a paradigm shift, a new and radical policy direction that would bring sanity, stability and investor confidence into it. We attempted an overview of the industry from the SAP regime to the consolidation and post-consolidation era, showing the different trends and challenges that overshadowed the industry and the various policy responses to them.

Particularly, we demonstrated that the crises in the banking industry are not an isolated phenomenon, but represent a broader problem - that of an ideology that is morally and ethically deficient, and which has brought more misery to the poor and vulnerable. And that is that the economic man is or must be driven by self-interest. In other words selfishness and greed is axiomatic, and forms the basis of our theoretical postulations. This greed then is expressed in the quest to charge more on loans and less on deposits. It has led to the rabid quest for primitive capital accumulation, a subtle euphemism for stealing, at both the political and economic sphere. It has led most to live beyond their means, stockpiling debts upon debts at the society's expense. This is not just a Nigerian problem but a global one. Human nature untamed and unbridled is the same everywhere (Effiom and Ubi, 2010). Those entrusted with the management of our collective patrimony loot, squander and personalize our collective assets for themselves and their families. But this must not continue. To stem this tide, we argue for a serious reconsideration of the philosophy of economics itself. This, we believe, is at the heart of the problem. Luckily, we are not alone in this advocacy. Garba (2003), Essia (2005) and Ekpo (2009) have all lent their voices to this call. Ekpo, in particular, contends that development should be human centred and that capital-labour-technology mechanics of the neoclassical paradigm should be moderated with a human face. Specifically, we argue that non interest banking should be given a trial because its principles are more congenial to the ethical shifts that this paper is advocating for.

\section{References}

Adam, A. J. (2004). Bank Regulation, Risk Assets and Income of Banks in Nigeria.

Adeoye, \& Adewuyi. (2006). Benefits and costs of financial sector reforms: Nigeria's experience. In Benefits and Cost of Economic Reforms in Nigeria; Selected Papers for the 2005 Annual NES Conference.

Alashi. (2002). Banking Crisis: Causes, Early Warning Signals and Resolutions. NDIC Quarterly, 12(4), December.

Allen, F., \& Santomerro, A. M. (2006). The Theory of Financial Intermediation. The Wharton Financial Institutions Centre.

Brownbridge, Martin. (1998). The causes of financial distress In local banks in Africa and Implications for prudential policy. UNCTAD/OSG/DP/132.

Diamond, Douglas. (1984). Financial Intermediation and Delegated Monitoring. Review of Economic Studies, 51, 393-414. http://dx.doi.org/10.2307/2297430

Effiom L., \& Ubi, P.S. (2010). Sustainable Development and the Role of Institutions. Proceedings of International Conference on Development Studies, 5(5), University of Abuja, FCT, Nigeria

Ekpo, A. H. (2009). The Global Economic Crisis and The Crises in the Nigerian Economy. Presidential Address to the $50^{\text {th }}$ (Golden Jubilee) Conference of the Nigerian Economic Society Held at NICON Luxury Hotel, Abuja, 28-30 September, 2009.

Emenuga, C. (2005). The Outcome of Financial Sector Reforms in West Africa.

Essia, U. (2005). Issues in Modern Economic Thought, 3. The Evolution of Economics: Facts, Phantoms and Fictions. Saesprint Publishers, Calabar. 
Gale, Douglas, \& Hellwig, Martin. (1985). Incentive-Compatible Debt Contracts: The One-Period Problem. The Review of Economic Studies, 52(4), 647-663. http://dx.doi.org/10.2307/2297737

Garba, A.G. (2003). An Essay on the philosophy and methodology of Economics. In: The Teaching of Economics, the Cutting Edge of knowledge. A publication of the Nigerian Economic Society.

Lewis, Peter, \& Howard STERN. (1997). Shifting fortunes: The political economy of financial Liberalization in Nigeria. World Development, 25(1), 5-22.

Onwioduokit, \& Adamu. (2006). Financial Liberalization in Nigeria: An Assessment of Relative Impact. In: Benefits and Cost of Economic Reforms in Nigeria; Selected Papers for the 2005 Annual NES Conference.

Sanusi, S.L. (2010). The Nigerian Banking Industry: what went wrong and the way forward. (Being the full text of a Convocation Lecture delivered at the Convocation Square, Bayero University, Kano, on Friday 26 February, 2010 to mark the Annual Convocation Ceremony of the University).

Slater, J. (2007). World's Assets Hit Record Value Of \$140 Trillion. The Wall Street Journal. [Online] Available: http://online.wsj.com/article/SB116839213664272112.html (August 14, 2011)

Soludo. (2005). The Outcome of the Banking Sector Recapitalization and the Way Forward for the Undercapitalized Banks. The Abuja Management Review, 1(3), September.

The Economist. (2009). 12. [Online] Available: http://www.economist.com/world/europe/displaystory.cfm? (August 14, 2011)

Williamson, Stephen. (1986). Costly Monitoring, Financial Intermediation, and Equilibrium Credit Rationing. Journal of Monetary Economics, 18, 159-179. http://dx.doi.org/10.1016/0304-3932(86)90074-7

Table 1. Number of banks in Nigeria (1970 -2009)

\begin{tabular}{|c|c|c|c|c|c|c|}
\hline Year & \multicolumn{2}{|c|}{ Commercial banks } & \multicolumn{2}{|c|}{ Merchant banks } & \multicolumn{2}{|c|}{ Total } \\
\hline & No of Banks & No of Branches & No of Banks & No of Branches & No of Banks & No of Branches \\
\hline 1970 & 14 & - & 1 & - & 15 & - \\
\hline 1975 & 17 & - & 5 & - & 22 & - \\
\hline 1980 & 20 & 740 & 6 & 12 & 26 & 752 \\
\hline 1981 & 20 & 869 & 6 & 15 & 26 & 884 \\
\hline 1982 & 22 & 991 & 8 & 19 & 30 & 1010 \\
\hline 1983 & 25 & 1108 & 10 & 24 & 35 & 1132 \\
\hline 1984 & 27 & 1249 & 11 & 25 & 38 & 1274 \\
\hline 1985 & 28 & 1297 & 12 & 26 & 40 & 1323 \\
\hline 1986 & 29 & 1367 & 12 & 27 & 41 & 1394 \\
\hline 1987 & 34 & 1483 & 16 & 33 & 50 & 1516 \\
\hline 1988 & 42 & 1665 & 24 & 46 & 66 & 1711 \\
\hline 1989 & 47 & 1855 & 34 & 56 & 81 & 1911 \\
\hline 1990 & 58 & 1939 & 49 & 74 & 107 & 2013 \\
\hline 1991 & 65 & 2023 & 54 & 84 & 119 & 2107 \\
\hline 1992 & 65 & 2275 & 54 & 116 & 119 & 2391 \\
\hline 1993 & 66 & 2358 & 53 & 124 & 119 & 2482 \\
\hline 1994 & 65 & 2403 & 51 & 144 & 116 & 2547 \\
\hline 1995 & 64 & 2368 & 51 & 144 & 115 & 2512 \\
\hline 1996 & 64 & 2407 & 51 & 144 & 115 & 2551 \\
\hline 1997 & 64 & 2407 & 51 & 144 & 115 & 2551 \\
\hline 1998 & 54 & 2185 & 38 & 113 & 92 & 2298 \\
\hline 1999 & 54 & 2185 & 38 & 113 & 92 & 2298 \\
\hline 2000 & 54 & 2193 & 38 & 113 & 92 & 2306 \\
\hline 2001 & 90 & 2193 & - & - & 90 & 2193 \\
\hline 2002 & 90 & 2227 & - & - & 90 & 2227 \\
\hline 2003 & 90 & 2227 & - & - & 90 & 2227 \\
\hline 2004 & 89 & 3492 & - & - & - & - \\
\hline 2005 & 25 & & - & - & - & - \\
\hline 2006 & 25 & 3233 & - & - & - & - \\
\hline 2007 & 25 & 4200 & - & - & - & - \\
\hline 2008 & 24 & 4785 & - & - & - & - \\
\hline 2009 & - & 5335 & - & - & - & - \\
\hline
\end{tabular}

Source: CBN Statistical Bulletin, 2009 
Table 2. Average annual growth rates of number of banks/branches

\begin{tabular}{|l|l|l|l|l|l|l|}
\hline $1970-1986$ & 5.0 & 10.0 & 19.0 & 47.6 & 12.3 & 25.9 \\
\hline $1987-2003$ & 8.0 & 3.0 & 8.7 & 9.9 & 8.3 & 6.1 \\
\hline
\end{tabular}

Source: Adeoye and Adewuyi, (2006)

Table 3. Nigeria: extent of insider loans and non-performing loans in selected banks in liquidation as at the date of closure

\begin{tabular}{|c|l|c|c|}
\hline S/NO & \multicolumn{1}{|c|}{ Closed Banks/Dates } & $\begin{array}{c}\text { Ratio of Insider Loans to } \\
\text { Total loans(\%) }\end{array}$ & $\begin{array}{c}\text { Ratio of Non Performing } \\
\text { Loans to Total Loans (\%) }\end{array}$ \\
\hline 1 & Financial Merchant Bank(1994) & 66.90 & 99.50 \\
2 & Kapital Merchant Bank(1994) & 50.0 & 96.20 \\
3 & Alpha Merchant Bank(1994) & 55.0 & 90.00 \\
4 & United Commercial Bank(1994) & 81.00 & 90.00 \\
5 & Republic Bank(1995) & 64.90 & 98.00 \\
6 & Commercial Trust Bank(1998) & 55.90 & 100.00 \\
7 & Commerce Bank(1998) & 52.00 & 86.90 \\
8 & Credit Bank(1998) & 76.00 & 98.30 \\
9 & Prime Merchant Bank(1998) & $80 / 70$ & 100.00 \\
10 & Group Merchant Bank(1998) & 77.60 & 94.50 \\
11 & Nigeria Merchant Bank (1998) & 99.90 & 95.90 \\
12 & Royal Merchant Bank(1998) & 69.00 & 98.00 \\
\hline
\end{tabular}

Source: Adam, 2004 